\title{
The Importance of Collaboration in Pediatric Rehabilitation for the Construction of Participation: The Views of Parents and Professionals
}

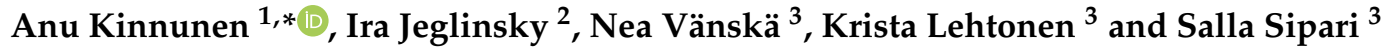 \\ 1 Department of Health and Wellbeing, Savonia University of Applied Sciences, 70201 Kuopio, Finland \\ 2 Department of Health and Wellbeing, Arcada University of Applied Sciences, 00560 Helsinki, Finland; \\ ira.jeglinsky@arcada.fi \\ 3 Department of Rehabilitation and Examination, Metropolia University of Applied Sciences, \\ 00079 Helsinki, Finland; nea.vanska@metropolia.fi (N.V.); krista.lehtonen@metropolia.fi (K.L.); \\ salla.sipari@metropolia.fi (S.S.) \\ * Correspondence: anu.kinnunen@savonia.fi; Tel.: +358-44-785-6432
}

Citation: Kinnunen, A.; Jeglinsky, I.; Vänskä, N.; Lehtonen, K.; Sipari, S. The Importance of Collaboration in Pediatric Rehabilitation for the Construction of Participation: The Views of Parents and Professionals. Disabilities 2021, 1, 459-470. https:// doi.org/10.3390/disabilities1040032

Academic Editor: Michelle A. Meade

Received: 26 September 2021

Accepted: 25 November 2021

Published: 30 November 2021

Publisher's Note: MDPI stays neutral with regard to jurisdictional claims in published maps and institutional affiliations.

Copyright: (c) 2021 by the authors. Licensee MDPI, Basel, Switzerland. This article is an open access article distributed under the terms and conditions of the Creative Commons Attribution (CC BY) license (https:// creativecommons.org/licenses/by/ $4.0 /)$.

\begin{abstract}
Purpose: Collaboration between parents and professionals is essential to enable participation of children with disabilities. Participation is a widely researched topic in pediatric rehabilitation, and evidence for it providing opportunities for involvement and a sense of belonging in community and in larger society exists. There are, however, less research results on how collaboration builds participation pertaining to involvement in life situations. In collaboration with parents, therapists and teachers, the aim of the study was to describe factors that (a) promote and (b) prevent participation in life situations for school-aged children with disabilities, working towards participation in adulthood. Methods: The study applied a qualitative research design. The data was collected during the 2015-2016 academic year with five focus-group interviews by sampling procedure. The study involved five parents of children with disabilities, three therapists and two teachers. The research data was analyzed by inductive content analysis. Results: The results identified thirteen factors that promote child participation, with an emphasis on taking the child's individuality into account. There were three barriers, which focused on attitudes or technical issues. Conclusions: The results suggest that collaboration on child-related factors has been well identified and implemented, but collaboration on enabling environmental factors needs to be developed. The results can be utilized to design what adults' collaboration should focus on in promoting child participation.
\end{abstract}

Keywords: participation; collaboration; pediatric rehabilitation

\section{Introduction}

Participation in the child's close environment and everyday life has, during the last decade, become an important area of interest within rehabilitation and healthcare. This area of interest has been strongly influenced by family-centered care, the ecological approach and the International Classification of Functioning, Disability and Health (ICF), [1,2]. The definition of participation is multidimensional. In the ICF, participation is defined as "involvement in a life situation", reflecting the activity the child is engaged in within the environment where he/she lives and acts [3]. Participation enhances individuals' health, well-being [3] and quality of life [4]. A semantic analysis of the word participation shows that it can mean inclusion, belonging, having mutual responsibility, taking part, attending, engagement [5-7]. Thus, participation is not only a matter of taking part and being present in activities, but also influencing opportunities and decisions of one's own life course [8]. The child's opportunities in participation are linked to the promoting and restricting factors in the environment and the context within which the participation takes place $[9,10]$. Consequently, enhancing participation is closely linked to physical, social and 
attitudinal changes in the child's participation environment such as accessibility of the activity and supportive social relationships [11-13].

Even though participation-focused practice is the current evidence-based recommendation in rehabilitation and habilitation, clinical practices often focus mainly on improving body function and activities [14,15]. As described by Anaby et al., (2021), change is needed at both the individual level and at all levels of the rehabilitation delivery system in order to promote participation-focused practices and outcomes in rehabilitation. It is also essential to better understand the families' as well as the professionals' perspective of the different perceptions of participation [16].

Modern child research seeks to examine a child's life from the child's perspective, since the child is a legitimate member of society [17,18]. Today, children are identified as individuals who shape their own lives, learning and future, but who still need adult support. Children have the right to express themselves and to be heard and should be empowered to make decisions based on their individual ability and cognitive level $[19,20]$.

The Declaration of the Rights of the Child (1989) underlines the realization of the child's participation in everyday practice. In the Declaration, all activities should identify the child as an individual and support his or her personal development in the family environment. The aim is to support the child's growth to develop into a full and equal member of society [21]. Participation in everyday life and affirmative experiences in social contexts are needed to optimize the child's development in functioning and selfdetermination towards adulthood [11,22,23].

Children's participation in the immediate environment and community calls for them to face several transitions on the path from infancy to adulthood, such as starting day-care, preschool, primary and secondary school, and then tertiary studies. The environmental requirements and need for participation differ and become more demanding during each transition phase $[24,25]$. Furthermore, these transition phases include major developmental tasks (e.g., career choices, autonomy from parents). For adolescents with disabilities, transition also means a shift to adult healthcare and rehabilitation services, which can be challenging if the services do not meet the needs of the adolescent [26]. Therefore, the preparation for transition to adolescence and adulthood should start early on in childhood to enhance participation and agency in adulthood. According to the ecocultural theory, a child's development takes place and is built above all in everyday situations of action and interaction. This means that everyone involved in the child's growth environments need to work closely together, enabling good planning of appropriate developmental activities and participation [27]. Thus, collaboration between adults in the child's life is crucial. Despite this, research on children's rehabilitation has focused little on collaboration that enables participation from childhood to adulthood. For the child to develop competencies to act as an active participant in society, preparations for the future must begin early on [2].

The aim of the study was to describe factors that (a) promote and (b) prevent participation in life situations for school-aged children with disabilities. These factors were constructed in collaboration with parents, therapists and teachers in focus group discussions.

\section{Materials and Methods}

\subsection{Participants}

The study participants were selected using purposive sampling [28]. The participants $(\mathrm{N}=10)$ were recruited by rehabilitation instructors from Northern Savo area in eastern Finland. The researcher provided information about the study to the instructors, who invited families suitable for the study. Families indicated their willingness to volunteer to participate to the researcher by phone or email. The parents passed on the information provided by the researcher about the research to their child's therapist and teacher, who, after becoming interested, contacted the researcher. Parents and professionals who gave their consent to participate were contacted by the researcher to agree on a time and place for the interview. The collection of data was carefully planned. Focus group interviews 
were conducted with parents, therapists and teachers in their own groups as well as in mixed groups.

Inclusion criteria for participants were (1) teacher, therapist or parent of school-aged children receiving intensive medical rehabilitation (physical or occupational therapy) from the Social Insurance Institution of Finland and who took part in special education, (2) participating in the child's daily life and (3) have understanding and experience of the research phenomenon in various contexts in daily life. All the children aged 8-12 years had learning disabilities and physical disabilities at GMFCS [29] levels II to III. Ten participants fulfilled the inclusion criteria and gave their informed consent to participate (Table 1). The operating environments for the therapists were hospital, home, school and/or therapy facilities. They worked as professionals in public and private sectors.

Table 1. The study participants.

\begin{tabular}{ccc}
\hline \multicolumn{2}{c}{ Participants $(N=\mathbf{1 0})$} & Mean Age (Range) \\
\hline $\begin{array}{c}\text { Parents }(N=5) \text { of three primary } \\
\text { school children (age 8-12) }\end{array}$ & Mother $(N=3)$ & 42.7 (29 to 52 years) \\
\cline { 2 - 3 } Professionals $(N=5)$ & $\begin{array}{c}\text { Therapists }(N=3) \\
\text { (two physiotherapists and }(N=2)\end{array}$ & 41.3 (35 to 49 years) \\
& \begin{tabular}{c} 
one occupational therapist) \\
\cline { 2 - 3 } (one clachers teacher and one \\
special teacher $)$
\end{tabular} & 28.0 (30 to 26 years) \\
\hline
\end{tabular}

\subsection{Data Collection}

The study applied a qualitative research design. A qualitative research approach allowed the description of the phenomenon in a real life environment and approach to the phenomenon holistically [30]. The data was collected during the 2015-2016 academic year with five focus-group interviews (Table 2). The focus group interviews were selected as a data collection method enabling construction of information in parents', teachers' and therapists' discussions. The focus group was a multi-voiced group of people with interest, expertise and experience in the research phenomenon [30]. The focus group interviews were carefully designed to obtain perceptions within a permissive, non-threatening environment [31]. The interviews followed loosely theory-driven themes described in Table 2 and were followed up with open questions that allowed a multidimensional view of the phenomenon. The focus groups were partly divided according to professions and a parental group, and partly mixed with parents, teachers and therapists in the same group. The interviews were conducted by the first author (AK).

Table 2. The interview themes in the focus group discussions.

\begin{tabular}{ccc}
\hline Focus Groups & Participants & Focus Group Discussion Themes \\
\hline Interview 1. & Participants in their own groups & $\begin{array}{c}\text { Participants' perception of the } \\
\text { child's participation }\end{array}$ \\
\hline Interview 2. & Participants in mixed groups & $\begin{array}{r}\text { Factors promoting the child's participation in } \\
\text { school, home and therapy }\end{array}$ \\
\hline Interview 3. & Participants in their own groups & $\begin{array}{r}\text { Factors preventing the child's participation } \\
\text { in school, home, and therapy }\end{array}$ \\
\hline Interview 4. & Participants in mixed groups & $\begin{array}{c}\text { Factors of collaboration promoting } \\
\text { participation of a child with disability }\end{array}$ \\
\hline Interview 5. & All together & $\begin{array}{c}\text { Factors of collaboration promoting } \\
\text { participation of a child with disability }\end{array}$ \\
working towards participation in adulthood
\end{tabular}


The interviews lasted 20-60 min. The interviews were tape-recorded for spelling verbatim and recordings allowed the researcher to return to these situations in order to re-observe the situation [32]. In total, the data consisted of $10 \mathrm{~h}$ and $27 \mathrm{~min}$ of tape-recorded data and 160 pages of verbatim text (Times New Roman, font size 12, line spacing 1).

\subsection{Data Analysis}

This research data was analyzed by inductive content analysis [33]. First, the interviews were transcribed by the author $(\mathrm{AK})$ and the text was read several times to gain familiarity. Meanings and phrases with information relevant to the object of the study were identified and extracted together with the surrounding text to preserve the content. This was accomplished by searching for meaning units (thought entities) that answered the data analysis questions, which were: (a) what factors promote and (b) what factors prevent participation for children with disabilities, constructed in collaboration with parents, therapists and teachers in order to enhance the child's participation in adulthood.

Next, the data was divided into sections based on their content and these meaning units were abstracted and coded. The coded meaning units were grouped based on similarities and differences. By grouping the data, the codes with the same content were combined into a sub-category that was named with a concept closely describing the content. The abstraction reduced the number of categories by collapsing those that are similar or dissimilar into broader higher order categories. Each category was named using contentcharacteristic words. The formed categories were constantly compared with the interview material to characterize the original meaning. All in all, 13 sub-categories were grouped as a result of the data analysis.

\section{Results}

\subsection{Factors Promoting the Child's Participation in Life Situations through Adults' Collaboration}

The following factors were described as promoting factors for the child's participation in life situations with the adults collaborating: encountering and listening to the child, encouraging the child, supporting decision-making, making agreements together, openness and future-oriented activity in collaboration, establishing child-oriented goal setting, designing individual practices, supporting the child's friendships (Figure 1).

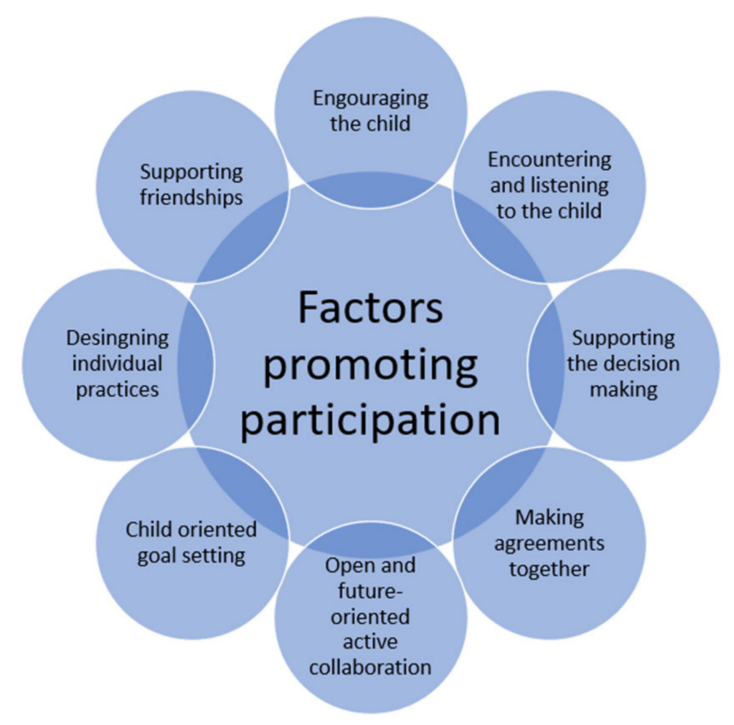

Figure 1. Factors promoting the child's participation in life situations.

Participants stated that encountering and listening to the child should be the starting point for collaboration. According to the participants, an adult should observe and listen to what is truly relevant to the child and thereby encourage the child to express her/his views. According to the data, the adult should be genuinely present and sensitive to 
listening to the child's message. The data described situations where the child had not been listened to. Situations where, for example, therapists had spoken to the parent over the child or, according to therapists and teachers, parents had decided on behalf of the child where, for example, activities and learning support would be organized and in what way, were observed.

"Adults should try to listen to children. Children's views should be taken into account.

The child can tell, if only he gets a chance." (Teacher 1)

The child should be supported to act independently and make his/her own decisions. According to the participants, the child should be involved in decision-making at home, at school and in therapy situations. Adults should, therefore, identify situations in which they should stand back in order to enable the child to function independently and enable space for the child's expression of his/her own perspectives.

"I have always considered it really important to be honest with the child and to encourage the child. You are an expert in your own affairs." (Parent 1)

"The child has to be involved in all the meetings where her issues are discussed and have an opportunity to say her own opinions, because she herself knows her own disability and needs well and tells them what is involved in her disability." (Parent 3)

The results highlighted the importance of making agreements between the child and the adults. It is important to make joint agreements with the child so that the child learns a goal-oriented and responsible approach for the future. The participants pointed out that agreements can be made in everyday situations, at home, for example, for homework, or in therapy when creating rehabilitation goals. In this way, the child learns to define activities that are relevant to him or her, to set goals, and to commit to and evaluate his or her own activities. This was also seen as an important tool in adult-child collaboration. Additionally, adults can make an agreement to clarify everyone's role in the collaboration.

Open and active collaboration is one of the most important factors in the requirements of participation. Such collaboration looks at seamless communication, information sharing and good interaction between different participants. Collaboration seeks common commitment and open discussion together. The research material showed that the adults should look at the child's future together. The activities that are done today, with the child, will have an impact on the child's activities in the future as well.

"Not so that parents do their own path, therapists and teachers their own, but parents together with others." (Parent 5)

In their activities together with the child, adults need to consider what the child's own dreams and hopes for the future are like. All policies should support this goal in the long run. How can a child be allowed to grow into a successful, independent adult? This should be possible early on in childhood.

"Not just managing somehow in life, but to live the most diverse and rich, happy everyday

life as possible." (Parent 3 )

It is important to set goals through meaningful activities for the child. "For example, music can be something for a child to gain enabling experience of succeeding." (Therapist 1) According to the participants, setting child-centered goals requires enabling the child to act independently and to be consulted in the child's own language. This helps them to get motivated and stay motivated.

"In both the rehabilitation and school worlds, the child should be part of the goal setting.

Not just the object, but the child himself should be creating his own goals." (Therapist 1)

Adults should also look at their behavior in relation to child orientation. In childcentered alternative modes of action, the adult settles down to look at actions and behaviors from the child's world. According to the data, actions should always be done individually utilizing the child's potential and his or her strengths. 
"If weight training is boring in therapy for the child, then it should be considered what would be an alternative training. For example, in downhill skiing we do exactly the same thing but on skis. That child could find motivation for action. Of course, it demands a bit from all of us adults, but you don't always have to see it through those same lenses. I feel like child's ideas can sometimes be pretty awesome, that I'd like to try something like that." (Therapist 1)

Friendships are one of the most important things for a child to support participation. Therefore, adult practices should be child-centered (for example, through play) and enabling friendships. Peer support is also related to the child's friendships. When comparing, two worlds of experience are combined. For a child with disabilities, these relationships are relevant. He gains experience working with a peer and understands that he is not the only one with special features.

"Peers also give strength and alternatives to the child and adults should support friendship building." (Teacher 2 )

The results of the study emphasized the need for open interaction, joint doing and active learning together. There must be trust between the child and the adult, and collaboration must be based on it. It is important also to recognize what kind of action is meaningful and possible for the child.

\subsection{Factors Preventing the Child's Participation in Life Situations in Adults' Collaboration}

Factors preventing the child's participation were physical barriers, prejudices, attitudes and lack of shared information and common language and understanding of roles in collaboration (Figure 2).

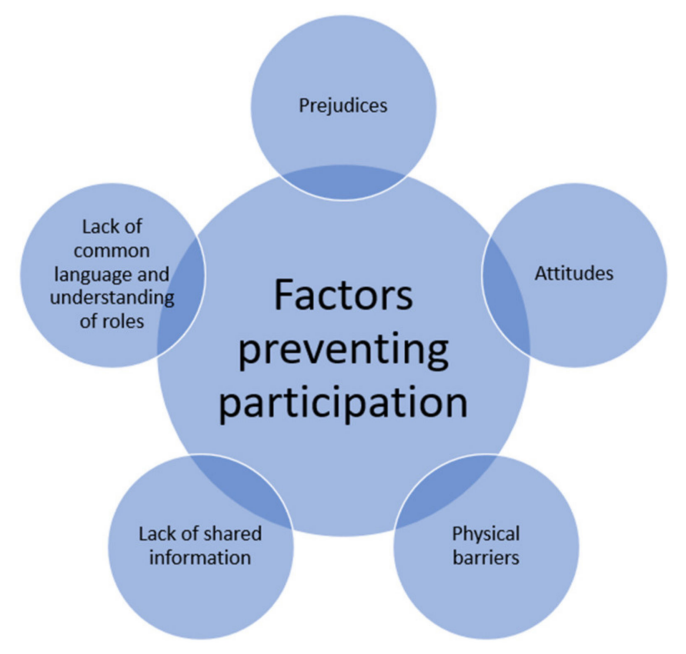

Figure 2. Factors preventing the child's participation in life situations.

It emerged from the results that adults' prejudices about the child's interests and opportunities for action can be a barrier to the child's participation. Adults' actions are regulated by their own values and attitudes and this appears in the behavior of adults and therefore affects the child's ability to participate. Attitudes can be negative out of fear of things that are not so familiar to them. Attitudes affect an adult's encounter with a child and the ways in which he or she interacts with the child. Participants stated that prejudices can be affected by fears that may arise from the support requirements and possible aids of children with disabilities. Additionally, adults may not have sufficient information about diagnoses, treatment, care or support needs.

"The one whose disability is visible is able to be directed at it and is placed in a different position. There are certainly other children out there who need special attention and special support and a different approach to getting and being able to receive the informa- 
tion that is passed on in class. That wheelchair does not stop a child from thinking and learning and using his head." (Parent 5)

Physical barriers in the environment such as old buildings with thresholds, narrow passageways or toilets without easy access, limit the child's opportunities for involvement especially for a child who uses mobility aids. Additionally, the participants stated that it is important to consider where the collaboration between family and professionals physically takes place. Professionals' environment such as hospitals or rehabilitation clinics may influence how included the child and parent feel and their possibility to contribute to the collaboration.

"Somewhere in the countryside there was a school in an old building where the toilet could only be built upstairs, so a child in a wheelchair could visit the toilet once a day only." (Therapist 2)

"Environment has a huge affect on the child and parents. For example a clinical environment, like a hospital, may make it difficult to understand a home environment and its needs. In the home, the atmosphere is freer for the child and parents to express thoughts and ideas." (Parent 3)

According to the results, counterproductive collaboration between parents, teachers and therapists may be due to, for example, lack of information, lack of a common language or a lack of understanding of another person's role. Professionals' perception or understanding of the individual daily life of the family, was a relevant factor. For example, if the therapist did not understand the family's daily routine or factors related to parents' coping or resources, collaboration was perceived as challenging. Professionals, on the other hand, describe the attitude of parents to the child's activities and collaboration with other adults as a barrier to collaboration. For example, teachers and therapists describe the role of a parent with a child as challenging in some situations.

"In some situations, parents try to be more as a friend to the child, rather than be a parent. Giving too much freedom to the child, for example playing video games at anytime. That can be a problem in school or therapy sessions when the child is forbidden to do that." (Teacher 1)

\section{Discussion}

The aim of this study was to describe factors that promote and prevent participation in life situations for school-aged children with disabilities, constructed in collaboration with parents, therapists and teachers. The results show that there are several promotive factors in adults' collaboration, whereas there are fewer preventing factors. In Figure 3, the main results are reconstructed in relation to the theories used in the study in an interactive relationship chart. Ecocultural theory and the ICF emphasize a child's development and participation in daily routines and versatile life situations where collaboration in rehabilitation should take place or should be linked [19,34]. The child's rehabilitation is an interactive process between a child and the environment [35] and in adults' collaboration. Factors promoting and preventing participation can be related to these components. According to the results, the child's participation is promoted in everyday life situations, by encouraging, listening, as well as supporting the child's decision-making and goal setting. The interaction needs to be open, active and based on jointly agreed matters. Individual practices are planned, and the child is supported in making friends. The results show that adults' collaboration focuses on supporting the child's friendships rather than enabling situations where the child could actively make friends herself/himself.

An important factor for promoting participation in collaboration is adults having a joint understanding of the meaning of participation in rehabilitation (the upper row in Figure 3). According to the results, an independent and self-determined, rich and unique life as well as a positive identity, seem to be the main ingredients to enhance participation. Collaboration that promotes participation, enables the child's power and responsibility towards his/her own affairs, strengthens the child's self-esteem and self-efficacy and 
pays attention to the child's dreams and wishes. This goes for both goal-setting and an individual life (Figure 3).

\begin{tabular}{|c|c|c|c|}
\hline $\begin{array}{l}\text { The meaning of } \\
\text { participation }\end{array}$ & $\begin{array}{l}\text { Independent \& } \\
\text { self-determined life }\end{array}$ & $\begin{array}{l}\text { Positive identity } \\
\text { in the course of life }\end{array}$ & Rich \& unique life \\
\hline $\begin{array}{l}\text { Construction in } \\
\text { collaboration }\end{array}$ & $\begin{array}{l}\text { Power and responsibility } \\
\text { as influencers }\end{array}$ & $\begin{array}{l}\text { Self-esteem and self- } \\
\text { efficacy } \\
\text { as strengths }\end{array}$ & $\begin{array}{l}\text { Dreams and aspirations } \\
\text { as drivers of goals and } \\
\text { life }\end{array}$ \\
\hline \multicolumn{4}{|c|}{$\begin{array}{l}\text { Everyday routines } \& \\
\text { diverse life situations }\end{array}$} \\
\hline $\begin{array}{l}\text { Construction in } \\
\text { collaboration }\end{array}$ & $\begin{array}{l}\text { Child } \\
\text { related factors }\end{array}$ & $\begin{array}{l}\text { Interaction } \\
\text { related factors }\end{array}$ & $\begin{array}{l}\text { Environment } \\
\text { related factors }\end{array}$ \\
\hline Promote & $\begin{array}{l}\text { Encouraging, } \\
\text { Listening, } \\
\text { Supporting decision } \\
\text { making, } \\
\text { Goal setting }\end{array}$ & $\begin{array}{l}\text { Making agreements } \\
\text { together, } \\
\text { Open and active } \\
\text { collaboration }\end{array}$ & $\begin{array}{l}\text { Designing individual } \\
\text { practices, } \\
\text { Supporting friendships }\end{array}$ \\
\hline Prevent & - & $\begin{array}{l}\text { Lack of information, } \\
\text { Lack of common } \\
\text { language, } \\
\text { Lack of understanding of } \\
\text { roles, } \\
\text { Professionals' lack of } \\
\text { understanding the } \\
\text { family's daily life }\end{array}$ & $\begin{array}{l}\text { Barriers in physical } \\
\text { environments, } \\
\text { Prejudices, } \\
\text { Attitudes: fear of } \\
\text { unfamiliar things, } \\
\text { insufficient information } \\
\text { about diagnoses, } \\
\text { treatment and support } \\
\text { needs }\end{array}$ \\
\hline
\end{tabular}

Figure 3. Synthesis of the main results and theories.

In the discourse of adults' collaboration, which promotes or prevents participation, the child or his/her function appeared to be an object of the support instead of the child being an active actor with whom opportunities for action are created. Surprisingly, only a few barriers to the child's functioning appeared in the results. This might be due to the fact that support for the child and his/her functioning is, from the participant's view, mainly seen as a facilitator. However, barriers in relation to the interaction and the physical environment were identified. Apart from the physical environment, identified barriers to participation were lack of information, a common language, a joint understanding and fear of unfamiliar things (Figure 3). Few factors, however, focused on the environment from a broader perspective. Most of the results pointed to practices on how adults enhance participation through interaction with the child, but not on targeting the needed modifications to the physical, social and attitudinal environment in the participational context. Physical barriers were mentioned, but these are usually visual and easy to observe. Additionally, professional attitudes were something that parents brought up as a barrier. Additionally, in a study by Maciver et al., (2019), the importance of the adults' attitudes towards creating opportunities for the child's participation were underlined, as well as the need for an individualized approach and flexibility in the routines and structures within the school environment [13]. From the child's perspective, factors such as suitable assistive devices and adaptations to activity demands, have been identified as relevant factors for meaningful participation in a previous study by Vänskä et al., (2020) [10]. Additionally, positive peer-relationships are important for the children [10,12].

In this study's results, children's possibility to influence goal setting and to establish meaningful goals was a central practice in enhancing participation in collaboration. Collaborative goal setting in Pritchard's et al., study (2020) with the child actively engaging in the process, enabled the identification of functional and motivational goals [36]. Costa et al., 
(2017) presented that in setting rehabilitation goals, adults focused more on the children's competencies and abilities instead of enjoyable social participation that was prioritized by the children themselves [37]. Sipari et al. [38] found that children value agreement and that agreed things were taken care of. Enabling children to take responsibility for what has been collaboratively agreed on, seem to be important factors in promoting participation towards adulthood. Additionally, King et al., (2020) presented that young people, parents and service providers valued different aspects of collaboration [39]. Hence, different perspectives of children, parents and professionals, should be acknowledged and negotiated in order to establish shared understanding of collaborative rehabilitation that enhances the child's participation in adulthood. Thus, to develop a shared understanding for collaboration, these different perspectives should be identified and intertwined. Palisano et al., (2012) presented an assessment tool for the collaborative process in order to reach the child's participation goal [40]. Vänskä et al., (2021) also presented a tool that could be useful to enhance the participation focused and collaborative approach in the child's daily life contexts, with the child as an active actor [41]. In the future, best tools and practices should be co-created in close collaboration with children, parents and professionals.

\subsection{Limitations}

Researcher triangulation was both a limiting and contributing factor in the internal validity of the study. One researcher conducted the interviews and data analysis, which strengthened the logical implementation of these phases, but this may have been a limitation to the entire research group's interpretation of the results and conclusions. However, this was anticipated by careful data management and documentation which enabled transparency, moving back and forth between data, data analysis tables and the researchers' discussion throughout the process. Thus, the internal validity was checked in the research group and credibility of the study was ensured with exact reporting.

The group of participants was small. The small sample size limits the generalization of the results in this study. However, the study population was well represented for the purpose of the study. As a method, the focus group interview was relevant as a data collection method. Yet, larger representation of professionals or other stakeholders might have resulted in more multifaceted perspectives of the phenomenon. The collection of data was carefully planned. Focus group interviews with parents, therapists, and teachers in their own groups as well as in mixed groups increased the possibility for broader discussions. Even though the data was saturated, because no new categories emerged in the latest data analysis, a larger and more versatile selection of participants might have revealed more promoting or preventing factors. Focus group discussions promoted both the richness of the data and reality of the practice because the information was built collaboratively. This turned out to be a good solution when the point of interest was practical and results were intended to be used for developing collaboration among parents, therapists and teachers. However, it is notable that the results of the study are described from the perspective of adults. Taking children's perspectives into account in the study would have added value to the results.

\subsection{Future Directions}

The results raise the question of whether promotion of participation pays attention to the child's functional capacity and environmental factors according to the components of the ICF classification, or whether attention and research should be paid to the interaction between the components.

According to the results, collaboration lays the foundation and a path for a child with disabilities working towards participation in adulthood. Even when the focus of doing and collaboration is in the present moment, the future should be kept in mind in such a way that the child is allowed to dream of a unique, rich and good future. In the child's rehabilitation, there is a great deal of emphasis on goal setting. In addition to setting goals, the results of this study suggest that children's rehabilitation should 
envision also the child's independent, rich and good future with children and adults collaborating together. Further research could focus on methods for foreseeing the future, such as reminiscing about the future with children. A tool guiding the co-creation and evaluation of collaborative practices could be useful to further develop the collaborative practices between child, family and professionals in the changing life circumstances and environments of the child.

\section{Conclusions}

This study's findings describe factors promoting and preventing the child's participation in life situations constructed in collaboration with parents, therapists and teachers. According to the findings, child-related factors in collaboration are well identified, but there is a lack of focus on the needed changes in the child's daily environment in order to enhance the child's participation. The study results emphasize the need to create a joint understanding of the meaning of participation in rehabilitation and to enable the child's active role in collaboration related to the child's daily life environments. The information gained through this study enables adults to view and analyze their own and the activities of their community in planning, implementation and evaluation, thereby enabling participation in the child's everyday life.

Author Contributions: Conceptualization, A.K.; methodology, A.K., I.J., N.V., K.L. and S.S.; project administration, A.K.; writing—original draft, A.K., I.J., N.V. and K.L.; writing—review and editing, S.S. All authors have read and agreed to the published version of the manuscript.

Funding: This research received no external funding.

Institutional Review Board Statement: The study was conducted according to the guidelines of the Declaration of Helsinki, and the research approval was obtained from University of Eastern Finland. Ethical review and approval were waived for this study by Ethics Committee of the Pohjois-Savo Hospital District. The committee stated that ethical approval for this kind of study was not needed. According to the ethical guidelines a study where data collection is a one-off, cross-sectional interview that do not interfere with an individual's physical or mental integrity does not need ethical approval. In this case the informants were professionals and adults (parents), and the topic were supporting participation, i.e., nothing that interferes with the participant's or the parent's child's integrity. In accordance with the ethical guidelines stated in the Helsinki declaration, generally accepted scientific principles was followed in the study. The design and procedure of the study was clearly described, and the results was objectively reported. Additionally, the participants signed an in-formed consent to participate and were informed of the right to refuse to participate or to with-draw their consent to participate at any time without reprisal.

Informed Consent Statement: Informed consent was obtained from all subjects involved in the study.

Data Availability Statement: The data presented in this study are not available due to participant privacy.

Conflicts of Interest: The authors declare no conflict of interest.

\section{References}

1. Vargus-Adams, J.N.; Majnemer, A. International Classification of Functioning, Disability and Health (ICF) as a framework for change: Revolutionizing rehabilitation. J. Child Neurol. 2014, 29, 1030-1035. [CrossRef] [PubMed]

2. Rosenbaum, P.; Gorter, J. The 'F-words' on childhood disability: I swear this is how we should think. Child Health Care Dev. 2011, 38, 457-463. [CrossRef] [PubMed]

3. World Health Organization. International Classification of Functioning, Disability and Health; WHO: Geneva, Switzerland, 2001.

4. Dahan-Oliel, N.; Shikako-Thomas, K.; Majnemer, A. Quality of life and leisure participation in children with neurodevelopmental disabilities: A thematic analysis of the literature. Qual. Life Res. 2012, 21, 427-439. [CrossRef] [PubMed]

5. Gustavsson, A. About the language of Participation. In The Language of Participation; Gustavsson, A., Ed.; Studentlitteratur: Lund, Switzerland, 2014; Volume 1, pp. 21-26.

6. Molin, M. Participation in the disability field. A conception analysis. In The Language of Participation; Gustavsson, A., Ed.; Studentlitteratur: Lund, Switzerland, 2004; Volume 1, pp. 61-80. (In Swedish)

7. Imms, C.; Granlund, M.; Wilson, P.H.; Steenbergen, B.; Rosenbaum, P.L.; Gordon, A.M. Participation, both a means and an end; a conceptual analysis of processes and outcomes in childhood disability. Dev. Med. Child Neurol. 2016, 59, 16-25. [CrossRef]

8. Sinclair, R. Participation in Practice: Making it Meaningful, Effective and Sustainable. Child. Soc. 2004, 18, 106-118. [CrossRef] 
9. Anaby, D.; Hand, C.; Bradley, L.; DiRezze, B.; Forhan, M.; DiGiacomo, A.; Law, M. The effect of the environment on participation of children and youth with disabilities: A scoping review. Disabil. Rehabil. 2014, 35, 1589-1598. [CrossRef]

10. Vänskä, N.; Sipari, S.; Haataja, L. What is meaningful participation? Photo-elicitation interviews of children with disabilities. Phys. Occup. Ther. Pediatr. 2020, 40, 595-609. [CrossRef]

11. Anaby, D.R.; Law, M.C.; Majnemer, A.; Feldman, D. Opening doors to participation of youth with physical disabilities: An intervention study. Can. J. Occup. Ther. 2016, 83, 83-90. [CrossRef]

12. Steinhardt, F.; Ullenhag, A.; Jahnsen, R.; Dolva, A.S. Perceived facilitators and barriers for participation in leisure activities in children with disabilities: Perspectives of children, parents and professionals. Scand. J. Occup. Ther. 2021, 28, 121-135. [CrossRef]

13. Maciver, D.; Rutherford, M.; Arakelyan, S.; Kramer, J.M.; Richmond, J.; Todorova, L. Participation of children with disabilities in school: A realist systematic review of psychosocial and environmental factors. PLoS ONE 2019, 14, e0210511. [CrossRef]

14. Adair, B.; Ullenhag, A.; Keen, D. The effect of interventions aimed at improving participation outcomes for children with disabilities: A systematic review. Dev. Med. Child Neurol. 2015, 57, 1093-1104. [CrossRef]

15. Novak, I.; Morgan, C.; Fahey, M. State of the evidence traffic lights 2019: Systematic review of interventions for preventing and treating children with cerebral palsy. Curr. Neurol. Neurosci. Rep. 2020, 20, 3. [CrossRef]

16. Anaby, D.; Khetani, M.; Piškur, B.; van der Holst, M.; Bedell, G.; Schakel, F.; de Kloet, A.; Simeonsson, R.; Imms, C. Towards a paradigm shift in pediatric rehabilitation: Accelerating the uptake of evidence on participation into routine clinical practice. Disabil. Rehabil. 2021, 1-12. [CrossRef]

17. Karlsson, L. Studies of Child Perspectives in Methodology and Practice with 'Osallisuus' as a Finnish Approach to Children's Reciprocal Cultural Participation. In Childhood Cultures in Transformation; Odegaard, E., Borgen, J., Eds.; Brill: Leiden, Norway, 2020; pp. 246-273.

18. Isola, A.M.; Kaartinen, H.; Leemann, L.; Lääperi, R.; Schneider, T.; Valtari, S.; Keto-Tokoi, A. Mitä osallisuus on? In Osallisuuden Viitekehystä Rakentamassa; THL: Helsinki, Finland, 2017.

19. Gal, T. An ecological model of child and youth participation. Child. Youth Serv. Rev. 2017, 79, 57-64. [CrossRef]

20. Woodhead, M. Foreword. In A Handbook of Children and Young People's Participation; Percy-smith, B., Thomas, N., Eds.; Routledge: London, UK, 2010.

21. United Nations. Convention on the Rights of the Child; General Assembly Resolution 44/25 of 20 November 1989; United Nations: New York, NY, USA, 1989. Available online: https://www.ohchr.org/EN/ProfessionalInterest/Pages/CRC.aspx (accessed on 20 November 2021).

22. Chiarello, L. Excellence in promoting participation: Striving for the 10Cs-client centered care, consideration on complexity, collaboration, coaching, capacity building, contextualization, creativity, community, curricular changes and curiosity. Pediatr. Phys. Ther. 2017, 29, 16-22. [CrossRef]

23. Marino, E.; Trembley, S.; Khetani, M.; Anaby, D. The effect of child, family and environmental factors on the participation of young children with disabilities. Disabil. Health J. 2018, 11, 36-42. [CrossRef]

24. Magill-Evans, J.; Wiart, L.; Darrah, J.; Kratochvil, M. Beginning the transition to adulthood: The experience of six families with youths with cerebral palsy. Phys. Occup. Ther. Pediatr. 2005, 25, 19-36. [CrossRef]

25. Rous, B.; Meyer, C.T.; Stricklin., S.B. Strategies for supporting transitions of young children with special needs and their families. J. Early Interv. 2007, 30, 1-18. [CrossRef]

26. Jeglinsky, I.; Salminen, A.-L.; Brogren, C.E.; Autti-Rämö, I. Rehabilitation planning for children and adolescents with cerebral palsy. J. Pediatr. Rehabil. Med. 2021, 5, 203-215. [CrossRef]

27. Grace, R.; Bowes, J. Using an ecocultural approach to explore young children's experiences of prior-to-school care settings. Early Child Dev. Care 2011, 181, 13-25. [CrossRef]

28. Stewart, D.W.; Shamdasi, P.N. Focus Groups: Theory and Practice, 3rd ed.; Sage: Thousand Oaks, CA, USA, $2014 ;$ p. 39.

29. Palisano, R.; Rosenbaum, P.; Bartlett, D.; Livingston, M. GMFCS—Gross Motor Function Classification System; Expanded and revised; Can Child Center for Disability Research: Hamilton, ON, Canada, 2007.

30. Wilkinson, S. Focus group research. In Qualitative Research: Theory, Method, and Practice, 2nd ed.; Silverman, D., Ed.; Sage: Thousand Oaks, CA, USA, 2004; pp. 177-199.

31. Adler, K.; Salanterä, S.; Zumstein-Shaha, M. Focus Group Interviews in Child, Youth, and Parent Research: An Integrative Literature Review. Int. J. Qual. Methods 2019, 18, 1609406919887274. [CrossRef]

32. Millward, L. 2012 Focus groups. In Research Methods in Psychology, 2nd ed.; Breakwell, G.M., Smith, J.A., Wright, D.B., Eds.; Sage: London, UK, 2012; p. 616.

33. Elo, S.; Kääriäinen, M.; Kanste, O.; Pölkki, T.; Utriainen, K.; Kyngäs, H. Qualitative Content Analysis: A Focus on Trustworthiness. SAGE Open 2014, 4, 2158244014522633. [CrossRef]

34. Maxwell, G.; Alves, I.; Granlund, M. Participation and environmental aspects in education and the ICF and the ICF-CY: Findings from a systematic literature review. Dev. Neurorehabil. 2012, 15, 63-78. [CrossRef]

35. Järvikoski, A.; Martin, M.; Autti-Rämö, I.; Härkäpää, K. Shared agency and collaboration between the family and Professionals in medical rehabilitation of children with severe disabilities. Int. J. Rehabil. Res. 2013, 6, 30-37. [CrossRef]

36. Pritchard, L.; Phelan, S.; McKillop, A.; Andersen, J. Child, parent, and clinician experiences with a child-drive goal setting approach in paediatric rehabilitation. Disabil. Rehabil. 2020, 1-8. [CrossRef] 
37. Costa, U.M.; Brauchle, G.; Kennedy-Behr, A. Collaborative goal setting with and for children as part of therapeutic intervention. Disabil. Rehabil. 2017, 39, 1589-1600. [CrossRef]

38. Sipari, S.; Vänskä, N.; Pollari, K. Lapsen Edun Toteutuminen Kuntoutuksessa. Osallistumista ja Toimijuutta Vahvistavat Hyvät Käytännöt. Sosiaali- ja Terveysturvan Raportteja 5/2017. Saatavilla Osoitteessa. 2017. Available online: https://helda.helsinki.fi/ handle/10138/220550 (accessed on 21 November 2021).

39. King, G.; Lisa, A.; Roger Ideishi, C.; D'Arrigo, R.; Smart, E.; Ziviani, J.; Pinto, M. The Nature, Value, and Experience of Engagement in Pediatric Rehabilitation: Perspectives of Youth, Caregivers, and Service Providers. Dev. Neurorehabilit. 2020, 23, 18-30. [CrossRef]

40. Palisano, R.J.; Chiarello, L.A.; King, G.A.; Novak, I.; Stoner, T.; Fiss, A. Participation-based therapy for children with physical disabilities. Disabil. Rehabil. 2012, 34, 1041-1052. [CrossRef]

41. Vänskä, N.; Sipari, S.; Jeglinsky, I.; Lehtonen, K.; Kinnunen, A. Co-development of the CMAP Book: A tool to enhance children's participation in pediatric rehabilitation. Disabil. Rehabil. 2021, 1-11. [CrossRef] 